\title{
LEAF MICROMORPHOLOGY OF Aesculus hippocastanum L. AND DAMAGE CAUSED BY LEAF-MINING LARVAE OF Cameraria ohridella Deschka \& Dimić
}

\author{
Elżbieta Weryszko-Chmielewska, Weronika Haratym
}

\author{
Department of Botany, University of Life Sciences, Akadeicka 15, 20-095 Lublin, Poland \\ e-mail: elzbieta.weryszko@up.lublin.pl
}

Received: 27.06 .2012

\section{Abstract}

The present study is a continuation of our research on the structure of healthy leaves of Aesculus hippocastanum and leaves damaged by larvae of Cameraria ohridella. In this study, the epidermal micromorphology of both leaf surfaces in $A$. hippocastanum was investigated by scanning electron microscopy (SEM). Light microscopy was used to examine on which side of the leaf blades eggs of Cameraria ohridella were laid. The characteristic features of the adaxial and abaxial epidermis were shown. In the hypostomatic leaves of the studied species, the stomata occurred at a density of $173 \times \mathrm{mm}^{-2}$ and they represented the cyclocytic type. A striated layer of the cuticle was observed only in the adaxial epidermis in which glandular hairs were also present along the midribs. Non-glandular trichomes grew only on the surface of the midribs or in their axils in the abaxial epidermis. We found eggs of $C$. ohridella only on the adaxial surface of the epidermis. Using SEM, we also observed in the mines leaf tissues damaged by $C$. ohridella. We found palisade parenchyma to be absent, whereas in the spongy parenchyma there could be seen large intercellular spaces and at places a dense mass of organic matter, formed from damaged cells and larval excrement. The vascular bundles and calcium oxalate crystals remained in the feeding places. We found numerous bacteria, fungal spores and hyphae as well as cleistothecia of Erysiphales in the mines on the surface of the damaged mesophyll.

The glandular trichomes occurring only locally on the leaves, the relatively thin cell walls of the epidermis and a not well-developed cuticle layer on their surface do not protect sufficiently these leaves against the invasion of $C$. ohridella. On the other hand, damaged tissue areas are a convenient place for the growth of bacteria and fungi.

Key words: Aesculus hippocastanum, leaf, epidermis, trichomes, stomata, Cameraria ohridella, eggs, larvae, tissue destruction

\section{INTRODUCTION}

The leaf is a plant organ that shows high morphological and anatomical variation as well as significant plasticity to adapt to ecological conditions (D i c $\mathrm{k}$ i s o n, 2000; B e l h a d j et al. 2007). The epidermal micromorphology, which includes cell shape and surface, stoma type as well as glandular and non-glandular trichomes, provides essential information used in plant classification which allows the determination of relationships between taxonomic units of different ranks (B u s s oti and Gros s oni, 1997; M o o n et al. 2009; B u naw an, 2011). The cell walls of the epidermis are a mechanical barrier that protects the plant against pathogens and herbivores (E v e r t , 2006; Underwood, 2012). The thickness of the outer wall and the presence of the cuticle and hairs play an important role (Wagner, 1991; B a r thlot t and Ne in hu is, 1997; Evert, 2006).

The anatomical features of the leaves of A. hippocastanum were presented in our previous papers (Haraty m, 2011; Weryszko-Chmielew $\mathrm{ska}$ and $\mathrm{H}$ ar at y $\mathrm{m}, 2011)$. Our study shows these leaves to be mesomorphic. Due to the location of stomata only in the abaxial epidermis, they are classified as hypostomatic leaves. The palisade parenchyma consists of one layer, while the adaxial epidermal cells are much larger than the cells of the abaxial epidermis. We also showed which structural elements of these leaves could be a physiological and mechanical barrier to $\mathrm{Ca}$ meraria ohridella larvae feeding in their parenchyma.

The aim of the present research was to continue the study on the leaf structural features of A. hippocastanum. The micromorphology of the adaxial and abaxial epidermis was compared using scanning electron 
microscopy as well as changes in the tissues damaged by $C$. ohridella larvae were observed. Microscopic observations of both surfaces of the leaf blade were also made to determine whether $C$. ohridella eggs were laid by the moths on the upper or lower leaf surface.

\section{MATERIALS AND METHODS}

The leaf micromorphology of common horse chestnut (Aesculus hippocastanum L.) was examined on plant material collected from trees growing in the city centre of Lublin during the period 2010-2012. This material was sampled in May, after eggs had been laid by Cameraria ohridella Deschka \& Dimić, and in July when the leaves showed changes caused by larval feeding.

A Nikon Eclipse 400 light microscope and a stereoscopic microscope equipped with a NIKON COOLPIX 4500 camera were used for microscopic examination. Slides were prepared from fresh leaves in which healthy sections and sections colonised by the horse-chestnut leaf miner were cut off. The glandular and non-glandular trichomes located on the surface of the veins were measured. The eggs were also observed and measured. The presence of different pathogens in the mines was recorded.

Leaf segments were also prepared for SEM examination; they were fixed in a $4 \%$ glutaraldehyde solution in $0.1 \mathrm{M}$ phosphate buffer with a $\mathrm{pH}$ of 7.0 and a temperature of $4^{\circ} \mathrm{C}$ for 12 hours. Next, the plant material was washed in the same buffer four times at 20-minute intervals and subsequently it was fixed in $1 \%$ osmium tetroxide for 1 hour. The leaf segments were dehydrated in alcohol series with the following concentrations: 30, 50, 70, 90 and 95\%, and immersed twice in absolute alcohol. After dehydration, the material was critical-point dried. The specimens were coated with gold and analysed using a TESCAN VEGA II LMU scanning electron microscope. In the healthy organs, the surface of the upper and lower epidermis with its outgrowths and the leaf cross sections were observed. The leaves with feeding remains left by the horse-chestnut leaf miner larvae were also viewed.

\section{RESULTS}

The margin of the leaf blade of A. hippocastanum is irregularly shaped (Fig. 1A). The epidermal cells on the surface of the teeth form a massive layer of striated cuticle (Fig. 1B).

\section{The adaxial epidermis}

In mature leaves, the epidermal cells of the upper leaf surface are irregularly shaped (Fig. 1C,D). Their outer wall is convex, while the cuticle layer shows striation. The proportions between the size of the epidermis and mesophyll cells in the leaf cross section are shown in Fig. 1E.

Few glandular trichomes, which are located only on the midrib surface (Fig. 1F, 3D), are found in the adaxial epidermis. The glandular trichomes consist of a 2-celled stalk and a spherical multicellular head. The average trichome height was $84 \mu \mathrm{m}$, while the head diameter was $61 \mu \mathrm{m}$. Non-glandular trichomes were not found on this leaf surface.

\section{The abaxial epidermis}

The epidermal cells of the leaf veins were significantly elongated, whereas the cells covering the areas between the bundles were irregularly shaped (Fig. 2A,B). The cuticle surface of the outer walls was smooth (Fig. 2B,C,D), except for the marginal regions of the leaf where distinct striae were found (Fig. 2C). Small striae were also observed on the surface of the epidermal cells near the stomata (Fig. 2D).

The stomata occurred only in the abaxial epidermis, at a density of 173 per $1 \mathrm{~mm}_{\mathrm{c}}$. The average stoma length and width were $24.6 \times 13.0 \mu \mathrm{m}$ (Table 1). The stomata of A. hippocastanum were classified as cyclocytic. They were arranged in different directions, at the level of other epidermal cells (Fig. 2C,D). The outer cuticular ledges of the guard cells were poorly developed.

Non-glandular trichomes, composed of 1-4 cells (Fig. 2A), were observed on the lower leaf surface. The trichome length ranged $116-436 \mu \mathrm{m}$. They were located on the midrib and lateral veins as well as in the vein axils.

In the SEM cross-section of the leaf vein, outer and inner walls of significant thickness were observed, (Fig. 2E), unlike the epidermal cells of the leaf blade between the veins.

\section{Leaf damage by the leaf-mining larvae}

Eggs of Cameraria ohridella were observed only on the adaxial surface of the leaf blades, both near the midribs and at other places (Fig. 3D). Egg size varied, with the average egg length and width being 416 x $300 \mu \mathrm{m}$. Developing larvae at different developmental stages could be seen in the egg cases (Fig. 3A-C). Young larvae (1-2 mm long) were observed in the leaf mesophyll in the first decade of May (Fig. 3E). In July we found different-sized larvae in the mines (Fig. 3G).

After the adaxial epidermis was removed from the leaf blade in the area of the mines, SEM examination found that the damage reached the spongy parenchyma in which large intercellular spaces could be seen (Fig. 3F, 4A). The larvae, which fed selectively, avoided the vascular bundles containing elements with thickened lignified walls (Fig. 4A,B). In the feeding areas, at some places there was a dense mass of organic matter formed from the remnants of damaged cells and larval excrement (Fig. 4B). Calcium oxalate druses, 
which had escaped from the cells and could pose a threat to the feeding larvae, were visible in the damaged tissues (Fig. 4 B-E,G). We also found clusters of crystals that had been formed by the disintegration of the druses (Fig. 4C,G). In some leaf sections, we observed fibrous structures that could be the start of a cocoon formed for last instar larvae (Fig. 4A,C).
In the mines, there were secondary infections caused by the penetration of pathogenic bacteria and fungi. Bacterial cells (Fig. 4C), fungal spores (Fig. 4G), fungal hyphae (Fig. 4A,B,D,E), and cleistothecia of representative of the order Erysiphales (genus Uncinula) were observed on the damaged tissues (Fig. 4F).
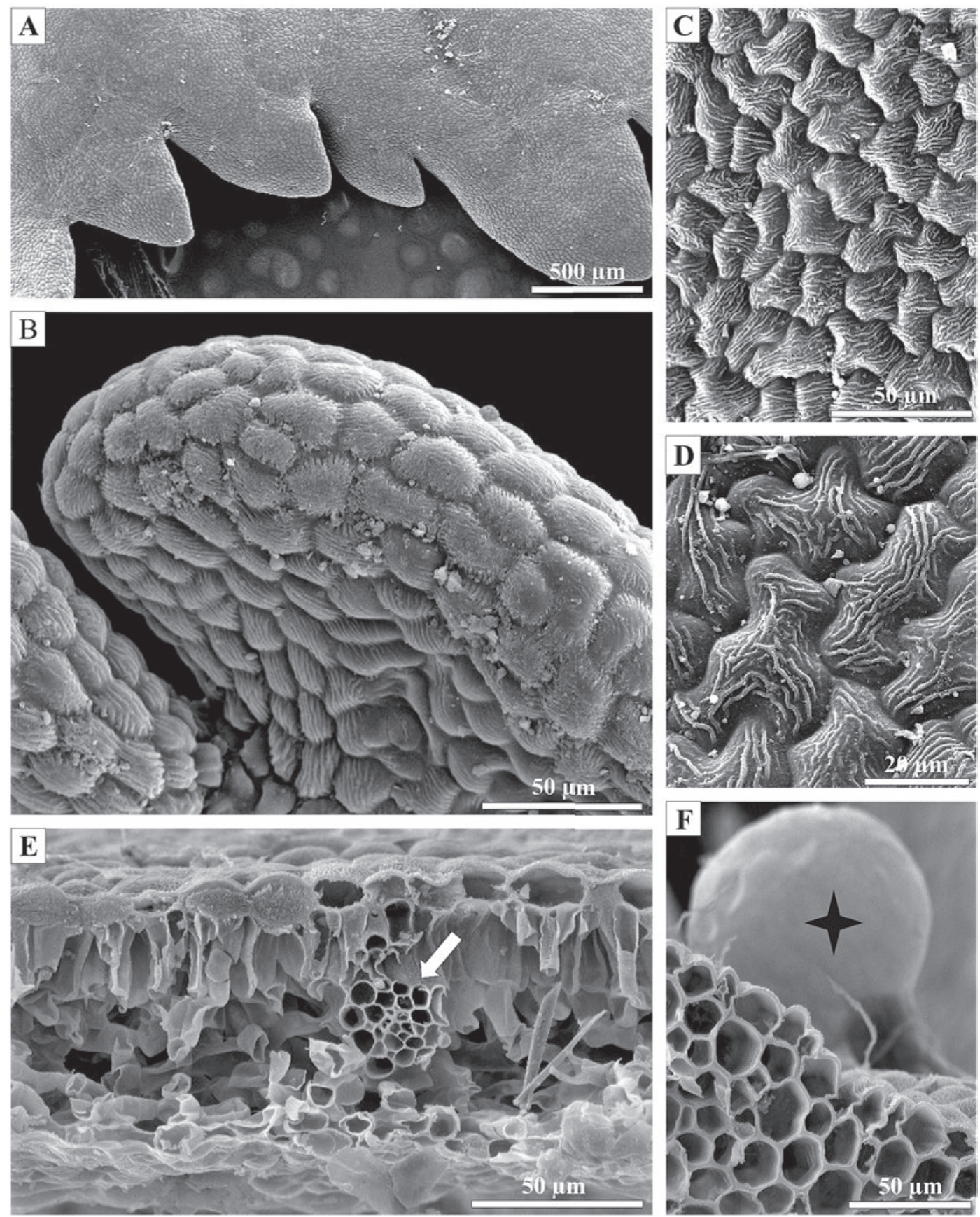

Fig. 1. Portions of the adaxial surface (A-D, F) and the cross section (E) of the leaf blade of Aesculus hippocastanum (SEM). A - Irregularly toothed margin of the leaf blade.

B - Massive cuticular striae on the surface of the walls of the epidermal cells in the marginal regions of the teeth.

C, D - Adaxial epidermal cells characterized by irregularly arranged cuticular striae.

$\mathrm{E}$ - Cross section of the leaf blade with a visible vascular bundle (arrow).

F - Glandular trichome on the upper surface of the leaf midrib (asterisk). 

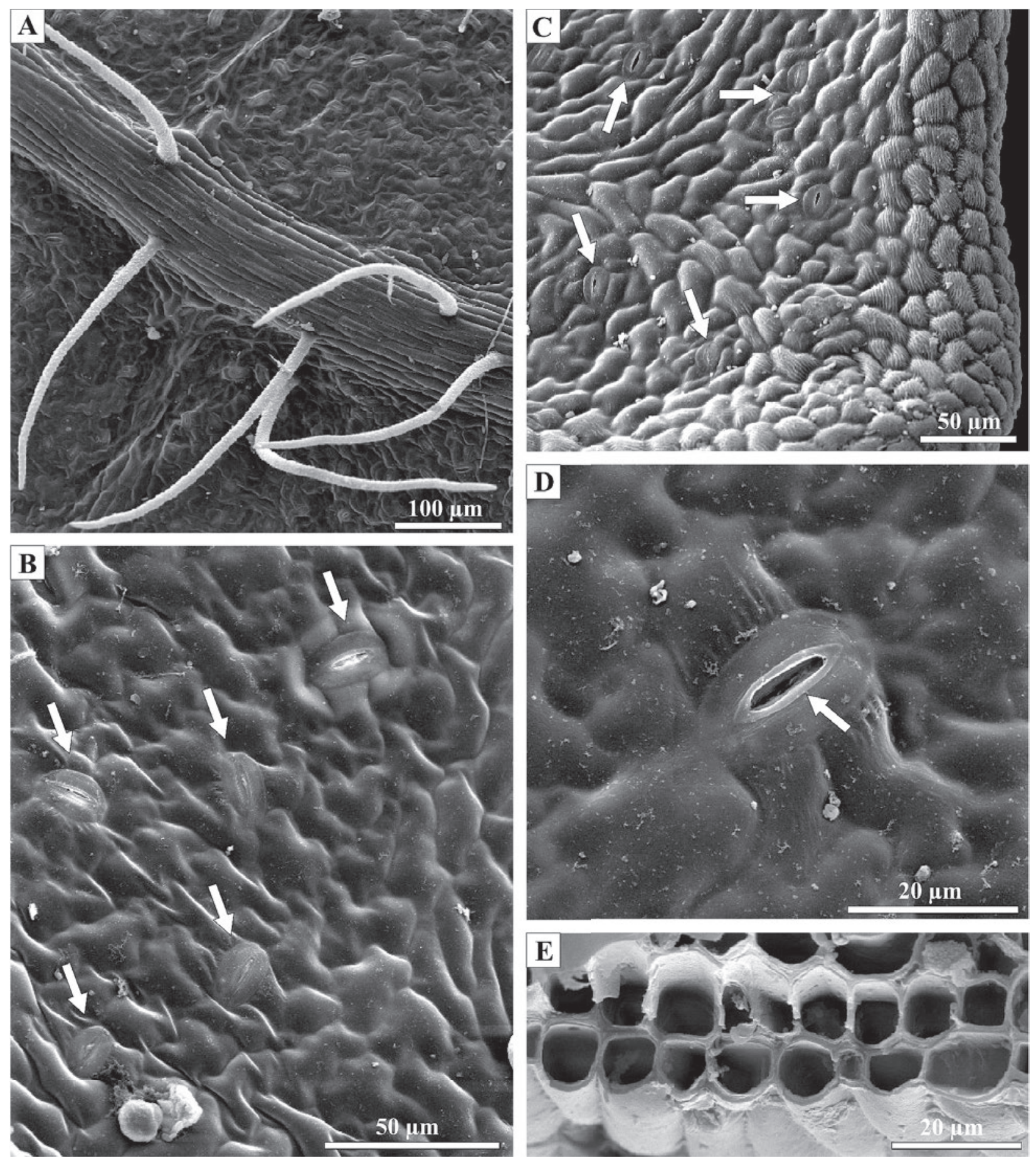

Fig. 2. Portions of the abaxial epidermis of the leaf of Aesculus hippocastanum (SEM). A - Non-glandular trichomes on the midrib.

B, C - Stomata arranged in different directions (arrows).

D - Stoma with poorly developed outer cuticular ledges (arrow).

E - Thickened walls of the epidermal and collenchyma cells in the lower part of the midrib. 

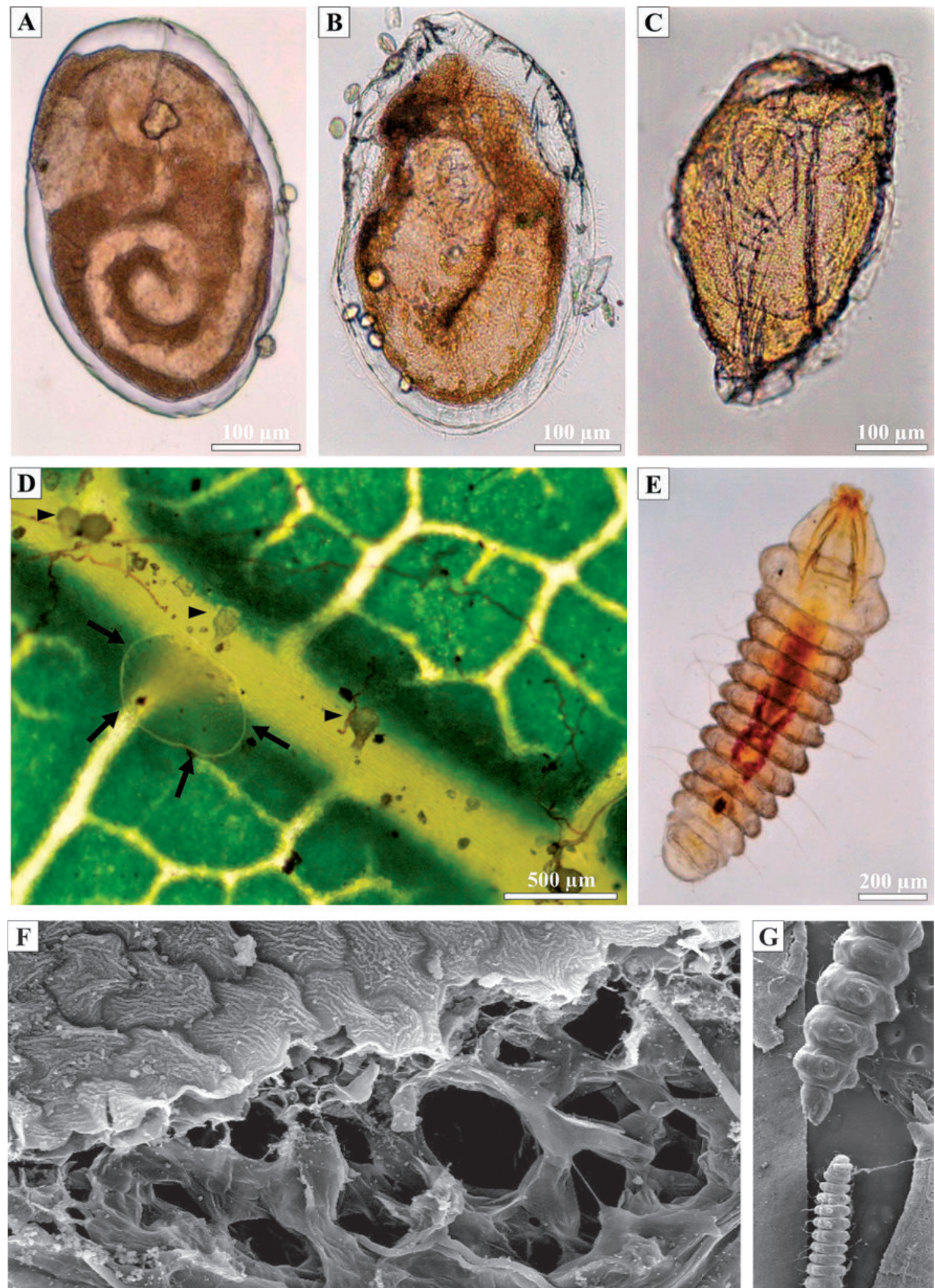

Fig. 3. Eggs and larvae of Cameraria ohridella as well as damage to the leaf tissues of A. hippocastanum. A - E - light microscopy; $\mathrm{F}, \mathrm{G}-\mathrm{SEM}$.

A, B, C - Eggs at different developmental stages.

D - Egg laid on the adaxial surface of the leaf near the midrib (arrows). The arrowheads show the glandular trichomes. E - C. ohridella larva found in a leaf of A. hippocastanum in the first decade of May.

$\mathrm{F}$ - Leaf tissue damage in a mine.

$\mathrm{G}$ - Larvae in different developmental stages found in the leaf tissues in July. 

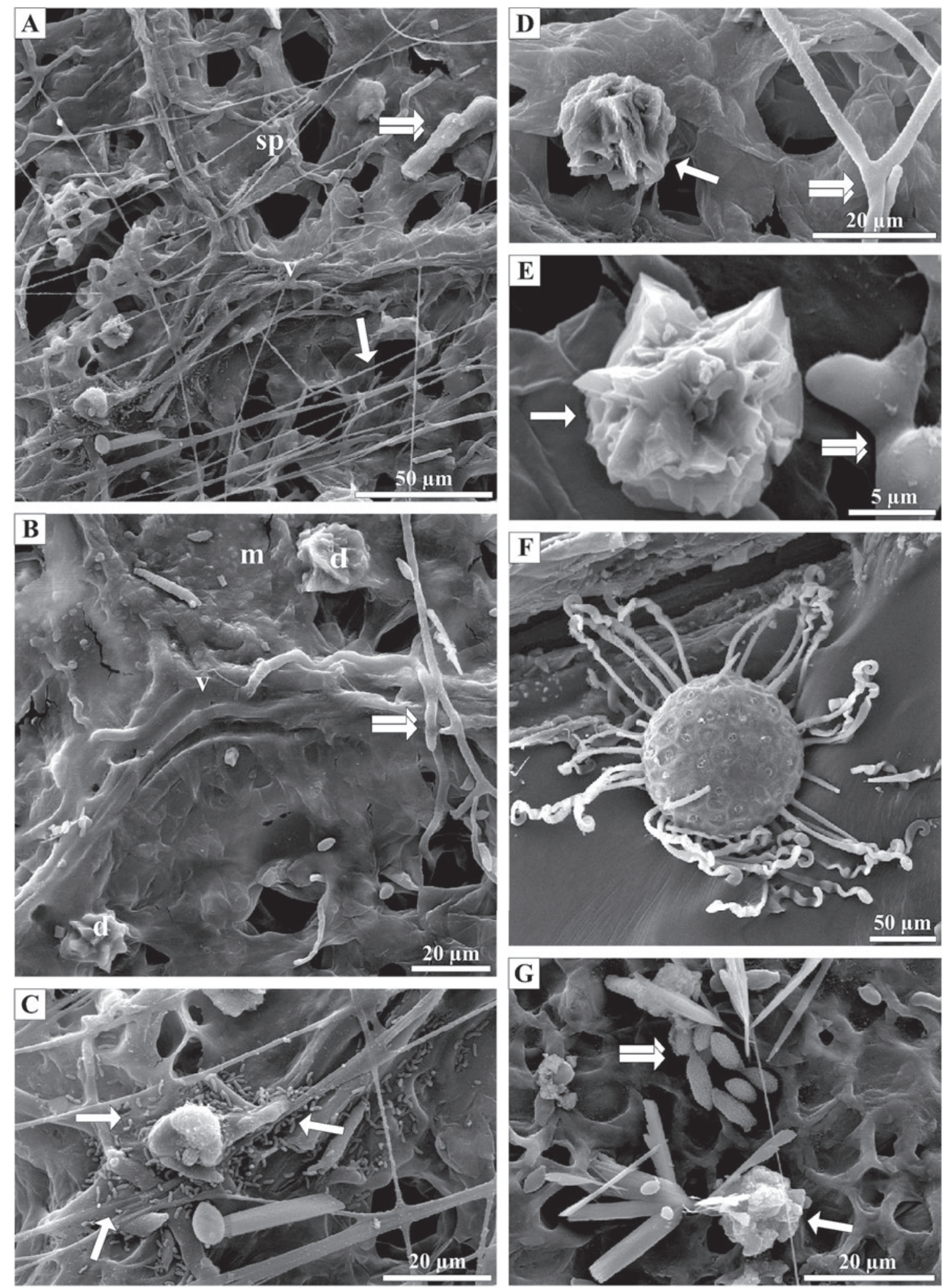

Fig. 4. Portions of the inner parts of the leaves of Aesculus hippocastanum damaged by feeding C. ohridella larvae (SEM).

A, B - Vascular bundles (v), spongy parenchyma (sp), and dense organic matter with larval excrement (m). On the surface of the damaged tissues, fibres of a cocoon of $C$. ohridella (arrows), druses (d), and fungal hyphae (double arrows) are visible. $\mathrm{C}$ - Numerous bacterial cells develop in the damaged mesophyll (arrows).

D, E - Calcium oxalate druses (arrow) and fungal hyphae (double arrows).

$\mathrm{F}$ - Cleistothecium of a fungus of the genus Uncinula (Erisiphales).

$\mathrm{G}$ - Clusters of calcium oxalate crystals (arrow) and fungal spores (double arrows). 
Table 1

Epidermal characteristics of Aesculus hippocastanum L. leaves.

\begin{tabular}{|c|c|c|c|c|c|c|c|}
\hline \multirow{2}{*}{$\begin{array}{c}\text { Some foliar } \\
\text { characters }\end{array}$} & \multicolumn{4}{|c|}{ Stomata } & \multirow{2}{*}{$\begin{array}{l}\text { Glandular } \\
\text { trichomes }\end{array}$} & \multirow{2}{*}{$\begin{array}{l}\text { Non-glandular } \\
\text { trichomes }\end{array}$} & \multirow{2}{*}{$\begin{array}{c}\text { Surface } \\
\text { epidermal cell }\end{array}$} \\
\hline & Number/mm, & Length $[\mu \mathrm{m}]$ & Width $[\mu \mathrm{m}]$ & Type & & & \\
\hline Adaxial surface & - & - & - & - & $\begin{array}{c}\text { capitate, } \\
\text { only in midrib }\end{array}$ & - & striated wall \\
\hline $\begin{array}{l}\text { Abaxial } \\
\text { surface }\end{array}$ & 173 & $\begin{array}{c}21.4-27.4 \\
(\mathbf{2 4 . 6 )}\end{array}$ & $\begin{array}{c}11.4-15.5 \\
\quad(\mathbf{1 3 . 0})\end{array}$ & cyclocytic & 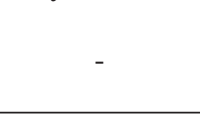 & $\begin{array}{c}\text { long, uniseriate, } \\
\text { in midrib and } \\
\text { other veins }\end{array}$ & $\begin{array}{l}\text { smooth } \\
\text { wall }\end{array}$ \\
\hline
\end{tabular}

\section{DISCUSSION}

Both the leaf anatomical features of Aesculus hippocastanum, described by us in our earlier papers (Harat y m 2011; Werys zko-Chmielew ska and $\mathrm{H}$ ar a t y $\mathrm{m}, 2011$ ), and the leaf micromorphology presented in this paper show that the leaf blades of this taxon have a structure typical of mesomorphic leaves developing in moderate light and humidity conditions. The characteristics of such leaves include the following: relatively thin outer walls of the adaxial epidermal cells, a not very thick layer of cuticle and the absence of wax, a single layer of palisade parenchyma composed of small cells, and poorly developed mechanical tissues.

In our study, we found eggs of $C$. ohridella only on the upper leaf surface. They were distributed irregularly at different places of the blade. Other authors have also found eggs of this moth to be laid on the upper side of the leaf (B a r a n ow ski, 2002; Grabenweger, 2003; Łabanowski and Soika, 2003). Only K reft et al. (2006) report that eggs of $C$. ohridella are attached to the lower surface of the leaf of A. hippocastanum.

Many authors emphasise that the cuticle layer on the epidermis of the plant organs is an important barrier to pathogens and herbivores ( $\mathrm{J} \mathrm{unipe} \mathrm{r}$ and Cox, 1973; B arthlott and Neinhuis, 1997; Evert, 2006). Small cuticular striae are visible on the cell walls of the adaxial epidermis. However, they are no obstacle for hatching $C$. ohridella larvae which chew through the epidermal layer and reach the palisade parenchyma.

In egg-laying and feeding of phytophages, the protective properties of leaves can be reinforced by non-glandular trichomes. Various studies have found that not only the density of trichomes on the epidermis surface plays an important role, but also their length (Webster, 1977; P app et al. 1992; Werys zko-Chmielewska and Soczyński, 1994; E is ne r et al. 1998). Because trichomes of this type are few on the leaves of A. hippocastanum and they occur only on the veins of the abaxial surface of the leaf, they probably do not play any role in the invasion of $C$. ohridella. Glandular trichomes can also deter or attract some insects by their secretion (L e v i n , 1973; Evert, 2006).

In the mines produced by $C$. ohridella in the leaves of A. hippocastanum, we observed numerous calcium oxalate crystals (druses) which, when released from the damaged cells, remained in the place of feeding. Calcium oxalate crystals in plant cells can perform different functions. One of them is protection against herbivory (Fin le y, 1999; S a lt z and W a rd, 2000; Molano-Flores, 2001; Evert, 2006). The formation of crystals in the cells is primarily the possibility of removing oxalates from plant organisms that are not capable of metabolising them (E v e r t , 2006). These crystals also enable detoxification of heavy metals ( $\mathrm{N} \mathrm{a} \mathrm{k} \mathrm{a} \mathrm{t} \mathrm{a} \mathrm{,} \mathrm{2003).}$

Calcium oxalate crystals formed in the leaves of A. hippocastanum only in some cells of the palisade and spongy parenchyma as well as in many cells occurring near the phloem of the larger vascular bundles. Lerste n and Horner (2008) also report that idioblasts with druses are found between the mesophyll cells in the leaves of Ticodendron, and their largest density is observed in the subepidermal parenchyma around the vascular bundles. Calcium oxalate crystals can occur in the phloem in which there is no conduction in the bark of many trees. In plants, druses are a frequently encountered form of calcium oxalate crystals that usually form in the vacuoles. They are spherical aggregates of prismatic crystals (E v e r t , 2006; Lersten and Horner, 2011).

Damage to the leaf tissues caused by $C$. ohridella larvae acts as a gate for secondary infections of these organs. In the mines, we observed numerous bacterial cells, fungal spores and fungal hyphae as well as cleistothecia of Erysiphales. They belong to pathogens developing on the leaves of $A$. hippocastanum ( $\mathrm{T}$ a 1 $\mathrm{g} o$ et al. 2012).

\section{Acknowledgements}

This research was supported by the Ministry of Science and Higher Education of Poland as part of the statutory activities of the Department of Botany, University of Life Sciences in Lublin. 


\section{REFERENCES}

Baranowski T., Parus A., Fajfer B. 2002. Występowanie szrotówka kasztanowcowiaczka (Cameraria ohridella Deschka \& Dimić) na kasztanowcach w Poznaniu w latach 2000-2001. / The occurrence of the horse-chestnut leaf miner (Cameraria ohridella Deschka \& Dimić) on horse chestnut trees in Poznań in the period 2000-2001. Progress In Plant Protection/ Postępy w Ochronie Roślin, 42: 654-657. (in Polish)

Barthlott W., Neinhuis C. 1997. Purity of the sacred lotus or escape from contamination in biological surfaces. Planta, 202:1-8.

Belhadj S., Derridj A., Aigony T., Gers Ch., Gauquelin T., Mevy J-P. 2007. Comparative Morphology and Leaf Epidermis in Eight Population of Atlas Pistachio (Pistacia atlantica Desf., Anacariaceae). Microscopy Res. Techn. 70:837-846.

Bunawan H., Talip N., Noor N. K. 2011. Foliar anatomy and micromorphology of Polygonym minus Huds. and their taxonomic implications. Austr. J. Crop Sci. 5(2):123-127.

Buss otti F., Gross oni P. 1997. European and Mediterranean oaks (Quercus L; Fagaceae): SEM characterization of the micromorphology of the abaxial leaf surface. Bot. Jour. Linn. Soc. 124:183-199.

Dickis on W.C. 2000. Integrative Plant Anatomy. Academia Press, San Diego, CA.

Eisner T., Eisner M., Hoebeke E.R. 1998. When defense backfires: Detrimental effect of a plant's protective trichomes on an insect beneficial to the plant. Proc. Natl. Acad. Sci. USA, 95:4410-4414.

Evert R.F. 2006. Esau's Plant Anatomy, Third Edition. John Wiley and Sons, Inc.

Finley D.S. 1999. Patterns of calcium oxalate crystals in young tropical leaves: A possible role as an anti - herbivory defense. Rev. Biol. Trop. 47:27-31.

Grabenwe ger G. 2003. Parasitism of different larval stages of Cameraria ohridella. BioControl, 48:671-684.

Haraty m W. 2011. Histologiczne uwarunkowania podatności kasztanowca zwyczajnego (Aesculus hippocastanum L.) na żerowanie szkodników. / Histological conditions of the susceptibility of common horse chestnut (Aesculus hippocastanum L.) to pest feeding. [In]: Młodzi naukowcy dla polskiej nauki. T. I. Cz.II - Nauki przyrodnicze. CREATIVETIME. Kraków: 179186. (in Polish)

Juniper B.E., Cox G.C. 1973. The Anatomy of the Leaf Surface: The First Line of Defence. Pestic. Sci. 4: 543561.

Kreft A., Skrzypek H., Kazimierczak W. 2006. Rola entomopatogenicznych nicieni w ograniczeniu liczebności szrotówka kasztanowcowiaczka (Cameraria ohridella). Materiały z Ogólnopolskiej Konferencji „Zwalczanie szrotówka kasztanowcowiaczka oraz innych owadów zagrażających zieleni miejskiej metodami nieinwazyjnymi”. Kielce, 14 lutego 2006. (in Polish)
Lersten N.R., Horner H.T. 2008. Subepidermal idioblast and crystal macropattern in leaves of Ticodendron (Ticodendraceae). Plant Syst. Evol. 276: 255-260.

Lersten N.R., Horner H.T. 2011. Unique calcium oxalate "duplex" and "concretion" idioblast in leaves on tribe Naucleeae (Rubiaceae). Am. J. Botany, 98(1): $1-11$.

Levin D.A. 1973. The role of trichomes in plant defense. Q. Rev. Biol. 48: 3-15.

Łabanowski G., Soika G. 2003. Szkodniki ozdobnych drzew liściastych. Plantpress. Kraków. (in Polish)

Molano-Flores B. 2001. Herbivory and calcium concentrations affect calcium oxalate crystal formation in leaves of Sida (Malvaceae). Ann. Bot. 88:387-391.

Moon H.K., Hong S-P., Smets E., Huysmans S. 2009. Phylogenetic significance of leaf micromorphology and anatomy in the tribe Mentheae (Neptoideae: Lamiaceae). Bot. Jour. Linn. Soc. 160:211-231.

Nakat a P. A. (2003): Advances in our understanding of calcium oxalate crystal formation and function in plants. Plant Sci. 164: 901-909.

Papp M., Kolarow J., Mesterhazy A. 1992. Relation between pubescence of seedling and flag leaves of winter wheat and its significance in breeding resistance to cereal leaf beetle (Coleoptera, Chrysomelideae). Environ. Entomol. 24(4): 700-705.

Saltz D., Ward D. 2000. Responding to a three - pronged attack: Desert lilies subject to herbivory by dorcas gazelles. Plant Ecol. 148: 127-138.

Talgo V., Spies Perminow J.I., Sletten A., Brurberg M.B., Herrero M.L., Stromeng G.M., Stensvand A. 2012. Fungal and bacterial diseases on horse chestnut in Norway. J. Agricult. Extention and Rural Devel. 4(9): 256-258.

Under w o od W. 2012. The plant cell wall: a dynamic barrier against pathogen invasion. Frontiers in Plant Science, doi: 10.3389/fpls.2012.00085.

Wagner G.J. 1991. Secreting glandular trichomes: More than just hairs. Plant Physiol. 96: 675-679.

Webster J.A. 1977. The cereal leaf Beetle in North America: Breeding for resistance in small grains. Ann. New York Academy of Sciences, 287: 230-237.

Weryszko-Chmielewska E., Haratym W. 2011. Changes in leaf tissues of common horse chestnut (Aesculus hippocastanum L.) colonised by the horse-chestnut leaf miner (Cameraria ohridella Deschka\&Dimić). Acta Agrobot. 64(4): 11-22.

Weryszko-Chmielewska E., Soczyński G. 1994. Cechy anatomiczne liści trzech odmian pszenicy ozimej (Triticum aesativum L.) a zasiedlanie roślin przez skrzypionki zbożowe, Oulema spp. (Coleoptera, Chrysomelideae). / The anatomical features of the leaves of three cultivars of winter wheat (Triticum aesativum L.) in relation to plant colonisation by cereal leaf beetles Oulema spp. (Coleoptera, Chrysomelideae). Acta Agrobot. 47(2): 53-62. (in Polish). 


\section{Mikromorfologia liści Aesculus hippocastanum L. i uszkodzenia wywołane przez minujące larwy Cameraria ohridella Deschka \& Dimić}

\author{
Streszczenie
}

Obecna praca stanowi kontynuację naszych badań dotyczących struktury zdrowych liści Aesculus hippocastanum i uszkodzonych przez larwy Cameraria ohridella. Analizowano mikromorfologię epidermy obu powierzchni liści $A$. hippocastanum w skaningowym mikroskopie elektronowym. W mikroskopie świetlnym oceniano, po której stronie blaszek liściowych składane sąjaja Cameraria ohridella. Wykazano charakterystyczne cechy epidermy doosiowej i odosiowej. W hypostomatycznych liściach badanego gatunku aparaty szparkowe występowały w zagęszczeniu $173 \times \mathrm{mm}^{-2}$ i reprezentowały cyklocytyczny typ. Prążkowaną warstwę kutykuli obserwowaliśmy tylko $\mathrm{w}$ doosiowej epidermie, gdzie obecne były również włoski gruczołowe wzdłuż nerwów głównych. Włoski mechaniczne wyrastały tylko na powierzchni nerwów oraz w ich kątach w obrębie odosiowej epidermy. Jaja $C$. ohridella znaleźliśmy jedynie na powierzchni doosiowej epidermy. W mikroskopie skaningowym obserwowaliśmy również uszkodzone przez $C$. ohridella tkanki liści w obrębie min. Stwierdziliśmy brak miękiszu palisadowego, zaś w obrębie miękiszu gąbczastego widoczne były duże przestwory międzykomórkowe, a miejscami zwarta masa materii organicznej, która powstała z uszkodzonych komórek i ekskrementów larw. W żerowiskach pozostały wiązki przewodzące i kryształy szczawianu wapnia. W obrębie min, na powierzchni zniszczonego mezofilu znaleźliśmy liczne bakterie, zarodniki i strzępki grzybów oraz kleistotecja Erysiphales.

Występujące na liściach tylko lokalnie włoski gruczołowe, stosunkowo cienkie ściany komórkowe epidermy oraz niezbyt dobrze rozwinięta warstwa kutykuli na ich powierzchni nie zabezpieczają w dostateczny sposób tych liści przed inwazją $C$. ohridella. Natomiast obszary uszkodzonych tkanek są dogodnym miejscem do rozwoju bakterii i grzybów. 
